\section{B A Institute of \\ YK Business Administration \\ 光 \\ Karachi \\ Leadership and Ideas for Tomorrow}

Business Review

Volume 10 Issue 2 July-December 2015

7-1-2015

\title{
Transferability of western MNCs human resource management practices: A case study
}

Mohammad Khasro Miah

North South University, Dhaka, Bangladesh

Shahid Hossain

North South University, Dhaka, Bangladesh

Follow this and additional works at: https://ir.iba.edu.pk/businessreview

Part of the Human Resources Management Commons, and the International Business Commons

\section{c) (7)}

This work is licensed under a Creative Commons Attribution 4.0 International License.

\section{Recommended Citation}

Miah, M. K., \& Hossain, S. (2015). Transferability of western MNCs human resource management practices: A case study. Business Review, 10(2), 148-160. Retrieved from https://doi.org/10.54784/ 1990-6587.1359

This article is brought to you by iRepository for open access under the Creative Commons Attribution 4.0 License and is available at https://ir.iba.edu.pk/businessreview/vol10/iss2/10. For more information, please contact irepository@iba.edu.pk. 


\title{
Transferability of Western MNCs Human Resource Management Practices: A Case Study
}

\author{
Mohammad Khasro Miah \\ North South University, Dhaka, Bangladesh \\ Shahid Hossain \\ North South University, Dhaka, Bangladesh,
}

\begin{abstract}
The purpose of this research is to understand the current prospect of Human Resources Management practices and its transferability in Bangladesh. This study was conducted in the US and UK MNCs operating in Bangladesh. In this study, in-depth interview and structure questionnaire methods have been used to collect data. The objectives of this study are to investigate insightful and classified information related to human resource management (HRM) practices and their transferability for both MNCs in Bangladesh. Study found that the transferability of MNC's HRM in South Asia, Bangladesh has a very bright and promising potential. The study has shown that the adaptability rate is very high and the host country companies are practicing HRM with successful combination of both, their host country's policies and practices as well as the home countries'. The position of HRM is broad and now open to all so the possibility of the transferability of MNC's HRM in Bangladesh is oblivious and is setting a vibrant remark in these days. The existing paper explores the employee cultural values of UK and US multinationals companies (MNCS) and their transformation of cultural adaptation on HRM practices in developing countries like Bangladesh.
\end{abstract}

Keywords: Human Resource Management Practices, Transferability, US and UK MNCs, Bangladesh.

\section{Introduction}

The numbers of international, multinational or global companies that we see these days are the reason of transferability of business (Hamel \& Prahalad, 1989). As a result, competitiveness has become an important factor and multinational companies (MNCs) now get the chance to stay competitive and fight for the deserving place. However, different MNCs have different workforces and they vary in interests, background portfolios, training procedures, and nationalities (De la Torre, 1990). Nowhere is it apparent that growing recognition of skills and core competencies required by the home companies will also be required by the host due to the structural changes of cultural diversity causing major challenges both in the international as well as domestic work patterns (Tung, 1988).

HRM has impact from various major factors when it comes to different countries and those impacts are basically relative. Those impacts are primarily economic, political, legal and historical environments (Sundaram and Black, 1992), employee demographics and labormarket characteristics (Teagarden, Butler, \& Glinow, 1992), socio-cultural characteristics of the workplace and society (Laurent, 1983). People's behavior is an interesting factor in culture and just because of this, in many studies conducted on MNCs it has been shown that, this people's behavior has created more buzz and interest in the field of comparative HRM (Brewster and Hegewisch, 1994; Schuler, Dowling, \& De Cieri, 1993). Sonja \& Phillips, 
(2004) have argued on the aspect of employees of an organization living within the crucial society. While employees of an MNCs develop collective sets of assumptions within the organizational structure which are important to that organization, nonetheless they also bring with them the various sets of assumptions MNCs carried and understood outside of the organization in the form of national cultures. This theory is supported by Sondergaard (1994) as he thinks one country's culture is the vastest used features to decentralize MNCs to run properly in a particular country when it comes to pressure.

Evidences are clear from different researches that employees' perceptions, values, and reaction to issues relating to SHRM practices are mainly attributed to different cultural identities which are also connected to their organizational commitment and job involvement. MNCs must be sensitive to the practiced values and attitudes in that country by keeping every aspect and situation in mind. So the cultural existence is no mean of assumption for any manager as they need to find out the existing values and norms of culture that should be practiced in every organization (Pratt \& Rafaeli, 1997).

\section{Internationalizing HRM}

The concept of The International HRM (IHRM) mainly focuses on MNCs as a 'head-office' driven company which constructs options as a function to analyze the strategic interpretation by the parent company's employees (Ngo, Tschudi, Gull, \& Ullu, 1998). The 'parent' practice of headquarters and international branch office is particularly problematic in the context of the Bangladesh. The relationship between the practices of the host country companies versus the parent MNCs are transnational in the sense that the host countries' companies may represent not only their own strategies based on their local contingent but they may also adopt the parent MNCs' practices as well, thus create a high chance for tension between foreign MNCs 'push' and 'pull' in relation to local environment (Farley, Hoenig, \& Yang, 2004). In this connection, it is clearly evident that without the power of the 'parent' company in the context of internal and external differences in the HRM practices tensions between local and foreign shareholders based on their respective expectations would ensure that hybrid or mixed practices will reflect relative power of parent MNCs in line with the host country's socio-legal environment.

\section{HRM Practices in Host Country}

Organizations and individuals are facing newer challenges in today's globalization era, because of the changing global market competitiveness (Schuler, 1992, Cascio, 1993, Pfeffer, 1994, Stavrou-Costea, 2002). It is necessary for the MNCs to build and keep their knowledgeable, skilled and talented human resources to stay competitive in the industry. Previous studies have confirmed positive association between HRM and a firm's performances (Huselid, 1995; Delery \& Doty, 1996; Huselid \& Delaney, 1996; Boselie, Paauwe, \& Jansen, 2001; Datta, Guthrie \&Wright, 2005; Tzafrir 2005). We know that the current business environment is rapidly changing and the reason behind it is the growing organizational success of the relationship. Eventually the HRM practices play the biggest role in order to create a more dynamic workplace environment by strategically being proactive (Brewster and Suutari, 2005).

Study by Schuler and Jackson (2007) has confirmed that in order to satisfy shareholders, customers, society and its other stakeholders a comprehensive HRM is the main path to follow. This can be reinforced with the prior study conducted into this area, for instance, according to Huselid (1995) HRM practices and turnover are connected just like the way productivity and firm's financial performances are linked to each other. His study further confirmed that high performance work practices are likely to have an effect on firm's performance where multiple HRM variables have significant impact. The study clearly established correlation between employee skills, organizational structure and employee 
motivation versus a firm's performance. But training and development were found to be different in his study. Huselid and Delaney (1996) contended HRM practices however. According to them the factors of selection and training are connected with the assumption of solid performance for both 'in profit' and 'nonprofit organization'.

'New Economy' era is new to Bangladesh but as the globalization concept is booming everywhere, Bangladesh has also moved into it and with the continuation of this situation the focus on people and knowledge has gradually increased with the global changes. The 'concept of HR' is new and a buzzword in Bangladesh; within last 7 to 10 time span it is widely practiced. Practice of having a dedicated HRM department has become a norm for the large organizations now a day. Companies face new challenges everyday which includes cases like shortage of talents, the importance of knowledge and ideas and the changing patterns and preferences of the labor market etc. As a result, successful and proper HR policies and strategies are needed for better future in the working field. As competition in the local and global arena is becoming fiercer, firms need to have more resilient, agile, adaptable and customer-driven in order to be successful. One must appreciate that HR department now has to become not only a strategic partner but also like a business partner due to the dynamic nature of ever changing environment. HR department has to see the big picture and should be able to influence key decisions and policies. In today's world, preservation of the strategic personnel and development of talents are being more focused by the HR departments.

\section{HRM Practices in US}

At a common level, the fundamental process involved in developing a group strategy in USA looks like of any strategic decision process. The basic steps should consist of (a) examining the firm's outside environment, (b) recognizing the strategic business issues that need to be spoken to, (c) pinpointing particular people issues that are critical to the success of the business, (d) developing a strategy to address the relevant issues, including connecting relevant metrics to the strategy, and (e) communicating the strategy. Though external environment and a firm's business strategies are considered as distinct issues both of them deserve to be treated as vital component of the entire process because a true understanding of the strategy cannot be gained without a deep knowledge of how that strategy attempts to position the firm in its external environment.

In terms of a firms' growth, sustainability and globalization challenges with a firm's business issues are most often addressed by the HR strategies. Other issues such as customercentricity, demographics, the changing psychological agreement, culture change, mergers and achievements, diversification, distribution channels, capability to launch new products, becoming a public company and the employee value intention are less tricky in USA. American organizations view issues such as retention, demographics, war for talent, changing psychological contract and employee value proposition as passive because they are treated as 'business issues' where they should be treated as 'people issues'. But regardless of how we term them one cannot deny that these issues are a matter of concern. Companies of USA have understood that they need to focus on human resource as they are unique and they are at the primary step of implementation.

\section{HRM Practices in UK}

Studies have confirmed positive relationship between firms' strategies and processes. For instance, Youndt, Snell, Dean, \& Lepak, (1996) have studied 512 manufacturing plants to find out the force of HRM strategy on firm's presentation and found a logical relationship connecting HR system and plant performance. According to Wright, Snell \& Dyer, (2005) positive relationship exist with organizational effectiveness when competitiveness of a firm is increased with high performance work system. Similar result was 
found by Gooderham, Ringdal \& Parry, (2006) where 3,281 firms in Europe have optimistic contact of HRM practices on firm performance.

The HRM policy was created because it is aligned to business and plays a strong role in the business strategy and that is the main reason why the term 'Strategic HRM' was taken. The survey gave us many issues to think about, for example, it most likely showed that the HRM function is becoming more important in organizations if one considers the indications given by the high percentages of HRM managers having places on the Board of Directors. The Scandinavian countries (Denmark, Norway and Sweden) had the highest percentage of organization's $(60 \%)$, which had written personnel or HR strategies, The Netherlands and Switzerland had over $50 \%$, while the rest, including The UK had less than $50 \%$. It can also be noted that of those which had a Personnel/HR strategy, only half to three quarters of them translated them into work programs which raises a substantial concern over the extent to which strategic human resource management in European MNCs is concerned.

\section{Methodology}

\section{Sampling and Data Collection}

In this qualitative study one US-based and one UK-based foreign MNCs subsidiaries operating in Bangladesh were selected. Table 1 provides background information of these two companies. In this study a judgment sampling was used with the intention of assemble indepth information to attain the purpose of the study. For this study a questionnaire, consisting of different dimensions of HRM practices and transferability of HRM practices were developed to collect the data from the selected companies. Some of the dimensions incorporated in the HRM practices questionnaire are: (i.e., educational investment, problem solving, in company welfare, long term commitment incentive) and transferability HRM practices (i.e., employment contracts, incentive and rewards, performance management, union influence, role of HR development, labor union characteristics). An official scheduled time with the HRM managers was planned, the questionnaire was handed in to the interviewees ahead of time, and face to face interviews with the interviewees were completed afterwards. From a selected $(8 \times 2) 16$ managers - human resource, administrative and factory - from the particular companies, data was collected with the designed questionnaire from all sixteen managerial respondents and, then, face to face semi-structured interviews were conducted.

A number of researchers have asserted that quantitative research methods may hold advantage with respect to deducting real-time information on different HRM practices of foreign subsidiaries (Martin \& Beaumont, 1999). On the other hand, for the purpose of understanding and comprehending the development process and the dynamic nature of HRM practices, demonstrated historical and longitudinal information have its characteristic of quantitative methods that will prove to be of little help.

This might be accredited to the insufficient capability of quantitative approaches to take into account the overall context. As a result, in regards to foreign MNCs companies, especially for HRM practices in foreign MNCs environment and their transferability issues , which involves a diversity of actors and as a result various background factors, a more suitable approach seems to be a qualitative one. In order to appropriately differentiate the findings, uniformity of research methods and research administration at the data collection stage were taken into consideration.

\section{Results}

Questionnaire has been prepared for finding out the real picture of HR in a UK Company and in an US based company. The results of the questionnaire are given below. 
Table 1: Transfer of Human Resource Management Practices between US and UK MNCs in Bangladesh

\begin{tabular}{|c|c|c|}
\hline Content & UK MNCs & US MNCs \\
\hline Employment contracts & $\begin{array}{c}\text { Contract based employment; } \\
\text { yearly renewal of contracts; } \\
\text { prefers internal sources over } \\
\text { external sources; follows CV } \\
\text { screening, interviews, references } \\
\text { and group interviews as selection } \\
\text { method }\end{array}$ & $\begin{array}{l}\text { Follows interviews, reference } \\
\text { and CV data as selection } \\
\text { methods; prefers external } \\
\text { sources; employment is based } \\
\text { on contracts. }\end{array}$ \\
\hline Incentives and Rewards & $\begin{array}{l}\text { Performance based incentives and } \\
\text { rewards; pays profit - share and } \\
\text { bonuses; pays gratuity as well; } \\
\text { transport facility for the factory } \\
\text { office. }\end{array}$ & $\begin{array}{l}\text { Practice of giving the basic pay } \\
\text { by salary survey among the } \\
\text { same industry; shares profits } \\
\text { and festival bonuses; gratuity } \\
\text { for permanent employees; } \\
\text { transport facilities. }\end{array}$ \\
\hline Performance Management & $\begin{array}{l}\text { Results are given in points }-1.1 \text {, } \\
1.2 \text { and the maximum point is } \\
3.3 \text {; Follows personal interview } \\
\text { between supervisor and written } \\
\text { reports. }\end{array}$ & $\begin{array}{l}\text { Results are given basis of } \\
\text { grade - A, B, C and the } \\
\text { maximum point is A. Primary } \\
\text { objective is to evaluate } \\
\text { performance to increase salary } \\
\text { and to give promotion. }\end{array}$ \\
\hline Union & $\begin{array}{l}\text { Collective bargaining is a } \\
\text { common practice; share opinions } \\
\text { in taking decisions. }\end{array}$ & $\begin{array}{l}\text { Active trade union; } \\
\text { participates in collective } \\
\text { bargaining; allowed to share } \\
\text { their needs and demands. }\end{array}$ \\
\hline Role of HR Department & $\begin{array}{l}\text { Strong HR department with } \\
\text { seven employees; two wings - } \\
\text { Compensation and Benefit and } \\
\text { Talent management; takes } \\
\text { decision for all employee related } \\
\text { issues and recruitment. }\end{array}$ & $\begin{array}{l}\text { Strong HR department; } \\
\text { maintains performance check, } \\
\text { safety of employees, the } \\
\text { compensation benefit and all } \\
\text { other HR related issues; } \\
\text { organized structure and have } \\
\text { different HR department for } \\
\text { the production area. }\end{array}$ \\
\hline $\begin{array}{l}\text { Labor Market } \\
\text { Characteristics: (Labor - } \\
\text { Employee Relation) }\end{array}$ & $\begin{array}{l}\text { Good labor - employee relation; } \\
\text { plenty of applicants; employees } \\
\text { get importance in work and } \\
\text { decision making. }\end{array}$ & 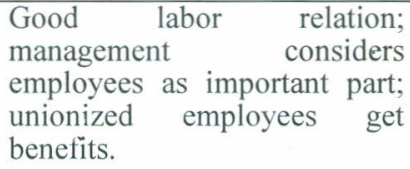 \\
\hline
\end{tabular}

Source: Adapted from Goodall and Warner (1997) 
https://ir.iba.edu.pk/businessreview/vol10/iss2/10

DOI: https://doi.org/10.54784/1990-6587.1359

Business Review - Volume 10 Number 2

July - December 2015

Table 2: Transferability of Human Resource Management Practices between US and UK MNCs in Bangladesh

\begin{tabular}{|c|c|c|}
\hline Content & UK MNCs & US MNCs \\
\hline \multicolumn{3}{|l|}{ Educational Investment } \\
\hline Introductory training & $\begin{array}{l}\text { Mandatory introductory training } \\
\text { for all employees. This training } \\
\text { basically takes part after the } \\
\text { recruitment and takes nearly a } \\
\text { month. }\end{array}$ & $\begin{array}{l}\text { Limited training programs; self } \\
\text { motivated employees; Training } \\
\text { programs are very limited in } \\
\text { here; general introductory } \\
\text { training is present. }\end{array}$ \\
\hline Task based training & $\begin{array}{l}\text { Training on particular task; not } \\
\text { for all the employees; specific } \\
\text { group gets the preference. }\end{array}$ & $\begin{array}{l}\text { Training is based } \\
\text { requirements; task based } \\
\text { training provided at the } \\
\text { beginning. }\end{array}$ \\
\hline Supervisory training & $\begin{array}{l}\text { For the managerial level; special } \\
\text { trainning for better management. }\end{array}$ & $\begin{array}{l}\text { For managerial and non- } \\
\text { managerial level } \\
\text { training is common }\end{array}$ \\
\hline \multicolumn{3}{|l|}{ Problem Solving } \\
\hline Suggestion system & $\begin{array}{l}\text { Strong chain of command; } \\
\text { employees share opinion; } \\
\text { problem solving solutions are } \\
\text { taken after departmental } \\
\text { meeting. }\end{array}$ & $\begin{array}{l}\text { Follows suggestion system for } \\
\text { internal problems. Employees } \\
\text { share opinion for solving } \\
\text { problems. }\end{array}$ \\
\hline QC circle Activities & $\begin{array}{l}\text { Good quality control } \\
\text { department; proper maintenance } \\
\text { of the quality; plant faces quality } \\
\text { check audit every year. }\end{array}$ & $\begin{array}{l}\text { Strong quality control } \\
\text { department; Internal Audit is } \\
\text { done twice a year; good quality } \\
\text { control over the organization }\end{array}$ \\
\hline \multicolumn{3}{|l|}{ In Company Welfare } \\
\hline $\begin{array}{l}\text { In company housing or } \\
\text { dormitory }\end{array}$ & $\begin{array}{l}\text { Limited in company housing or } \\
\text { dormitory for workers and very } \\
\text { specialized factory } \\
\text { administrative personnel }\end{array}$ & $\begin{array}{l}\text { Limited in company housing or } \\
\text { dormitory for workers only. }\end{array}$ \\
\hline Annual recruitment practices & $\begin{array}{l}\text { Recruitment is based upon the } \\
\text { need and the practice goes on } \\
\text { throughout the year. }\end{array}$ & $\begin{array}{l}\text { For the production area there are } \\
\text { annual recruitment practices but } \\
\text { for the management need the } \\
\text { recruitment practice varies. }\end{array}$ \\
\hline In-house newsletter & $\begin{array}{l}\text { Publishes annual in - house } \\
\text { newsletter. }\end{array}$ & $\begin{array}{l}\text { Publishes annual in - house } \\
\text { newsletter. }\end{array}$ \\
\hline In-house athletic meet & $\begin{array}{l}\text { UK MNCs encourages sports; } \\
\text { celebrates sports day and } \\
\text { organize competition. }\end{array}$ & $\begin{array}{l}\text { In the cultural day, the } \\
\text { management also organizes } \\
\text { sports competition. }\end{array}$ \\
\hline
\end{tabular}




\begin{tabular}{|c|c|c|}
\hline Housing loan & $\begin{array}{l}\text { Permanent employees have the } \\
\text { advantage of getting housing } \\
\text { loan. }\end{array}$ & $\begin{array}{l}\text { US MNCS doesn't provide this } \\
\text { facility to all but in some } \\
\text { exceptional cases this loan is } \\
\text { issued. }\end{array}$ \\
\hline \multicolumn{3}{|l|}{$\begin{array}{l}\text { Long Term Commitment } \\
\text { Incentive }\end{array}$} \\
\hline Long term employment & $\begin{array}{l}\text { Long term employment is } \\
\text { appreciated in UK MNCs in } \\
\text { Bangladesh. }\end{array}$ & $\begin{array}{l}\text { US MNCS also appreciate long } \\
\text { term employment but sometime } \\
\text { company recruit contractual } \\
\text { basis also. }\end{array}$ \\
\hline Seniority based practices & $\begin{array}{l}\text { UK MNCs the practice is mainly } \\
\text { based on the performance rather } \\
\text { than seniority. }\end{array}$ & $\begin{array}{l}\text { Seniority does get preference } \\
\text { but at a same time performance } \\
\text { also matters. }\end{array}$ \\
\hline Job Rotation & Job rotation is mandatory & Job rotation is mandatory \\
\hline $\begin{array}{l}\text { Recreational trip and Season's } \\
\text { recreational party \& Seasonal } \\
\text { vacation }\end{array}$ & $\begin{array}{l}\text { There is no seasonal vacation or } \\
\text { party in UK MNCs, but there is } \\
\text { an annual dinner. }\end{array}$ & $\begin{array}{l}\text { Seasonal party or vacations isn't } \\
\text { introduced in Bangladesh yet } \\
\text { but they have annual dinner. }\end{array}$ \\
\hline Retirement allowance system & $\begin{array}{l}\text { Employees do get after } \\
\text { retirement allowance. }\end{array}$ & $\begin{array}{l}\text { Retirement allowance system is } \\
\text { present in US MNCS in } \\
\text { Bangladesh }\end{array}$ \\
\hline Annual Salary System & $\begin{array}{l}\text { Employees get fund salary on } \\
\text { annual basis. }\end{array}$ & $\begin{array}{l}\text { Annually company has two } \\
\text { bonuses and one yearly bonus } \\
\text { and also has different funds. } \\
\text { Permanent employees have the } \\
\text { privileges on the fund. }\end{array}$ \\
\hline Promotion Practices & $\begin{array}{l}\text { Promotion takes place based on } \\
\text { the assessment and performance. } \\
\text { Generally it happens twice a } \\
\text { year. }\end{array}$ & $\begin{array}{l}\text { Experience and good } \\
\text { performance are the main motto } \\
\text { of promotion. }\end{array}$ \\
\hline Personnel Assessment System & $\begin{array}{l}\text { Personnel Assessment System } \\
\text { plays a very important role in } \\
\text { UK MNCs. Based on this the } \\
\text { promotion and other significant } \\
\text { decisions are taken. It takes } \\
\text { place twice a year. }\end{array}$ & $\begin{array}{l}\text { Management gives lot of } \\
\text { emphasis on the employee's } \\
\text { feedback and they try to make } \\
\text { change in them and process } \\
\text { according to that. }\end{array}$ \\
\hline Bonus System & $\begin{array}{l}\text { Three types of bonus systems; } \\
\text { Yearly bonus, gratuity bonus, } \\
\text { provident fund. }\end{array}$ & $\begin{array}{l}\text { The company has two festival } \\
\text { bonuses and one yearly bonus. } \\
\text { This system is fixed for all } \\
\text { permanent employees. }\end{array}$ \\
\hline Open Room Office Design & $\begin{array}{l}\text { The office currently they are in is } \\
\text { an old house so the design is not } \\
\text { of 'open room' to that extent in } \\
\text { particular. }\end{array}$ & $\begin{array}{l}\text { It has an open room office } \\
\text { design. The factory is more open } \\
\text { and it is designed in such a way } \\
\text { that all can work together. }\end{array}$ \\
\hline
\end{tabular}

Source: Adapted from Takeuchi and Chen (2001)

\section{Discussion}

The field of HRM has flourished a lot but this paper exemplifies that much remains to work on to make culture a global regulation. In this spirit this paper offers unanswered questions and presents a new framework and approaches to make SHRM practices more inclusive of cultures around the globe particularly in Bangladesh. It is hoped that this paper will arouse new discussions and debates making cross-cultural issues more of the median and less of the exception in the field of HRM. There is also the need for further research on the moderating influence of culture on relationships between SHRM practices, motivation and 
organizational performance in Bangladesh. SHRM practices and organizational presentation reconciled by HRM outcomes; this issue has become more significant and several researches have been done on this relationship (Budhwar and Katou, 2005). Some of the findings from this paper are summarized below.

The most commonly used HRM practices for preparing questionnaire contains employee recruitment and selection, training and development, performance appraisal, compensation and reward benefits and the trade union. All these practices are for maintaining employee welfare by practicing collective bargaining regarding the labor welfare and employee training and development. These items are basically developed by Huselid 1995; Youndt, Snell, Dean, \& Lepak, 1996; Datta, Guthrie \&Wright, (2005) to prepare their HRM practices questionnaire survey research.

While considering HRM practices firms need to think about several attributes. One of the most important practices that firms need to consider is recruitment and selection of employees. The variation of the external labor market conditions plays a significant role in the industry as well. While doing this research four important variables came out with strong significance and they were 'hiring employees with specialized skills', 'hiring employees with creative thinking skills', 'recruitment and selection process that fit with candidates in relations to their jobs' and 'organizations preference for internal recruitments to fill vacancies when promotions are concerned'. Huselid (1995), Siengthai \& Bechter, (2001), Dechawatanapaisal (2005), Minbaeva, (2005) and Purcell \& Hutchinson (2007) have used these variables extensively in their studies before.

Employee performance appraisal is another important key criterion. In this research several sub points were taken care of and these items were created and used by several authors (Huselid (1995), Pfeffer, (1998), Ngo, Tschudi, Gull, \& Ullu, (1998), Paul \& Anantharaman, (2003), Shah \& Ward (2003)). These points are: 'employee assessment criteria are clear', 'performance appraisal depends on the result', 'feedback is presented regularly by the management', 'employees are satisfied with the end result of performance appraisal', and 'employees commitment towards their work performance'.

In this research training and development had an important role and several important factors were taken into account. Some of those regarding training and development are 'new employees familiarize with organizational norms and values (orientation)', 'organization provides continuous training for updating employee skills and knowledge', 'training programmers are constantly revised or being updated to fit with present requirement', and 'all training programmers are of high quality'. Huselid (1995; Siengthai \& Bechter, (2001), and Dechawatanapaisal (2005) have used these items extensively in their previous studies.

The main points which are described in the research regarding employee compensation and reward are developed by Huselid (1995), Ngo, Tschudi, Gull, \& Ullu, (1998), (Paul \& Anantharaman, 2003; Minbaeva, 2005). This practice mainly focuses on four items including 'compensations system that harmonizes with employee's work and their working patterns, knowledge and skills', 'compensation system that rewards innovative ideas', 'good job performance is addressed and rewards are given in annual functions' and 'top management prefers employee participation in decision making with all levels of jobs'.

In this research we have seen that 'employee union is part of management', and 'union has an important role for productivity'. We have also found out that management puts a lot of emphasis on the union and their wellbeing. 
The connection between HR practices and organizational performance has always been focused but from other researches and studies it is clear that SHRM is being popular day by day in relation with HRM and its practices but the debate is going on. HR practices and SHRM work side by side in the organizational environment and SHRM takes HR practices as a strategic problem solver in case of the formulation and implementation of strategies. Studies by Paauwe, Boselie, \& Richardson, (2002), Barney and Tayler (1991) and Delery (1998) have confirmed that most of the SHRM practices have adopted the resource-based view (RBV) which place emphasis on gaining competitive advantage by adopting organizational resources through the employees.

The change has been made because of the resource-based view and it gave the strategic management to think from the inside in approach (Wright, P. M., T. M.; Gardner, et al. 2001). Barney and Tayler (1991) has believed that this view has actually helped the human resources management as it is the people who act differently in case of assumptions of value, rareness, inimitability, and no substitution; these are necessary for an organization's success. Questions had been raised regarding RBV theory's negligence on the importance of the contextual options and that includes the organizational structure which is crucial from HRM point of view.

Fields, Chan, \& Akhtar, (2000); Nyambegera, Sparrow, \& Daniels, (2000) and Miah and Wali (2012) debated on the nationwide culture because they thought this situational variable has certain authority on choosing HRM strategies. Therefore, worldwide simplification of results from such research has been questioned (Budhwar and Katou, 2005). MNCs have higher job responsibilities in care of marketing and all other organizational aspects such as HRM and so on than the smaller organizations and it is supported by Panayotopoulou, L., D. Bourantas, et al. (2003). Hofstede (1993, 1980) think that developing or less developed countries get less preference by western researchers where should get more preferences on the contrary.

The overall discussion and the study give us certain generalized ideas about the two companies' HR practices in Bangladesh and their transferability of HRM practices. Ideas derived from this study are summarized below.

UK MNCs' HR practices are richer than the US MNCs. American MNCs are still working on these issues. They are now integrating company strategy with HR strategy. Europe has become the business partner of the total organization and they are trying to enhancing it. As the field of HR is relatively a new function in Bangladesh, one can assume that Bangladeshi firms will be willing to adopt and to implement policies and practices that can be justified to complement Western philosophies regarding their HR practices. But still in Bangladesh the application of Strategic Human Resource Management is very low. The concept of integrating HR strategy with the business strategy is still absent in Bangladesh.

From this study it was understood that multinational organizations in Bangladesh are trying to implement new HR practices in a proper way but still they need to go a long way. There need to be more supervision from the global side. The local companies can learn from the foreign multinational organizations about the standard HR practices but they also lack in this point somewhere. It could be due to local people who are running the HR department.

Among the two companies covered in this report it was found that UK MNCs' HR is more involved than the US MNCs once the bigger picture is considered. The US MNCs need to be involved more. As most of the companies are emphasizing on producing and selling the product rather than getting competitive advantage through human capital American MNCs need to invest more in the organization's development. Though they are cost conscious they need to increase their knowledge as well as to motivate the employees and they need to provide training. 
Both UK MNCs and US MNCs need to take feedback from their customers and consumers. UK MNCs' HR does that but it is not done in a structured and formal way. They need to make it whole process and need to do these at a regular basis. It's extremely important that organizations need to align their HR strategy with the firm's strategy. They have done some small part but need to do more. And this should be extended to every sector of the HR ranging between compensation to operation and from talent management to organizational development.

\section{Conclusion}

From this study we found that a mixture of national cultures and their authority on employees' behavior encourage much optimism about rising perspectives on culture and SHRM practices. Organizations around the world have different mechanism regarding making decisions, allocating resources, negotiate, manage and motivate employees, and train and develop employees and there are several researches to support that. Most of these studies have uniformly accepted the fact that when it comes to organizational behavior culture becomes an important factor. The US and the Western Europe are given more attention (Triandis, 1994) by researchers and there are proofs regarding the statement. It is noteworthy to mention that performance appraisal has attracted a great deal of attention now a day. For instance, Levine, (1986) has identified the need for performance appraisal in the assessment of employee training needs, employee merit appraisal, employee salary determination, feedback on employees' past performance, and employee development. According to Thang (2004) how well an employee performs his job is influenced by the appropriation of HRM policies linked to decision making. As a result, while organizations gradually becoming more operational in a global work environment; their management practices are still primarily Western. Bangladeshi firms have strong potentials for practicing good HRM and one can say that the new concept of Strategic Human Resource will help to enhance the business as well as the environment more effectively. Organizations need to motivate their people and should consider their development as a moral obligation. When SHRM will be implemented the knowledge and skill of people of Bangladesh will be utilized better and the integration of SHRM with business strategy will also become fruitful. Time has come for organizations in Bangladesh to realize the fact that people working for Bangladeshi firms have immense potentiality that needs to be nurtured which will enlighten their organizations in many ways. The challenge however will be to implement appropriate HR policies and practices that are in line with the foreign MNCs which can harmonize with local ones keeping the local culture and context in mind. So now it is Bangladesh's turn to really absorb SHRM practices and implement for the grater result. As foreign direct investment is extremely important for us in terms of economic development and employment generation and competition in the global market place is becoming fiercer day by day as every LDC tries to attract FDI, it is increasingly becoming important that our firms start to manage their human resources in a different way to enhance their overall performance for their competitive advantage (Islam, M. Z: \& Siengthai, S., 2010).

\section{References}

Barney,J.B., \& Tayler,B.1991. The Prescriptive limits and potential for applying strategic management theory, Managerial and Decision Economics, in press.

Boselie, P., Paauwe, J., \& Jansen, P. (2001). Human resource management and performance: lessons from the Netherlands. International Journal of HumanResource Management,12, 1107-1125.

Brewster, C. and Hegerwisch, A. (1994). Human resource management in Europe: Issues and opportunities. In: Brewster, C. and Hegerwisch, A. (Eds.) Policy and practice in European human resource management: The Price Waterhouse Cranfield Survey. London: Routledge. 
Brewster, C., \& Suutari, V. (2005). Global HRM: aspects of a research agenda, Personnel Review, 34(1), 5-21.

Budhwar, P. and Katou, A. (2005). The effect of human resource management systems on organizational performance in Greek manufacturing: A mediating model. EURAM 2005 Conference, Munich.

Cascio, W.F. (1993), "'Downsizing: what do we know? What have we learned?", Academy of Management Executive, Vol. 7 No. 1, pp. 95-104.

Datta, D.K., Guthrie, J.P. and Wright, P.M., HRM and labor productivity: Does industry matter? Academy of Management Journal, 48(1), 2005, pp.135-145.

De la Torre, J. (1990). Managing in a Changing Global Economy: Paper presented at the Advanced Executive Program, Anderson Graduate School of Management, UCLA.

Dechawatanapaisal, D. (2005). 'The Effect Of Cognitive Dissonance And Human Resource Management On Learning Work Behavior For Performance Improvement: An Empirical Investigation Of Thai Corporations', Asian Institute Technology, Thailand, Dissertation: No. SM-05-03

Delery, J.E. 1998. Issues of fit in strategic human resource management: Implications for research. Human Resource Management Review. Vol 8 (3), 289-309

Delery. J.E. and Doty. H.D. (1996) 'Modes of Theorizing in Strategic Human Resource

Farley, J.U., Hoenig, S. and Yang, J.Z. (2004). Key Factors Influencing HRM Practices of Overseas Subsidiaries in China's Transition Economy. International Journal of Human Resource Management, 15(4-5): 688-704.

Fields, D., Chan, A, and Akhtar, S. (2000) Organizational Context and Human Resource Management Strategy: A Structural Equation Analysis of Hong Kong Firms International Journal of Human Resource Management Vol 11(2), 264-277

Gooderham, P., Ringdal, K. \& Parry, E. (2006). The Impact of Human Resource Management Practices on the Performance of European Firms. Paper Presented at the Copenhagen Business School Conference on HRM and Knowledge-Related Performance, September, 21 22.

Hamel.G.. Doz. Y.L. and Prahalad. C.K. (1989), "Collaborate with your competitors- And win", Harvard Business Review, Vol.89 No.1.PP.133-9.

Hofstede, G., (1980) Culture's Consequences. International Differences in Work Related Values. Sage, London.

Hofstede, G., (1993) Images of Europe, valedictory address delivered at the University of Limburg at Maastricht, 1 October 1993.

Huselid, M. A. (1995). The impact of human resource management practices on turnover productivity, and corporate financial performance. Academy of Management Journal, 38(3), 636-72.

Huselid, M. A., \& Delaney, J. T. (1996). The impact of human resource management on perceptions of organizational performance. Academy of Management Journal, 39(4), 949969. 
https://ir.iba.edu.pk/businessreview/vol10/iss2/10

DOI: https://doi.org/10.54784/1990-6587.1359

Business Review - Volume 10 Number 2

July - December 2015

Hutchinson, S. and Purcell, J. (2007) Line Managers in reward, learning and development, Research into Practice, London: Chartered Institute of Personnel and Development

Islam, M. Z. \& Siengthai, S. (2010). Human Resource Management Practices and Firm Performance Improvement in Dhaka Export Processing Zone, Research and Practice in Human Resource Management, 18(1), 60-77.

Laurent, A. (1983): The Culture Diversity of western concepts of Management, International studies of Management and Organization, Vol. XIII, No. 1-2,pp.75-96.

Levin, H. Z. (1986). 'Performance Appraisal at Work'. Personnel, 63(6), 63-71.

Management: Tests of Universalistic, Contingency, and Configurational Performance

Miah, M. Khasro \& Wali, Md. F. Ibne, (2012). Transferability of Chinese human resource

management practices in Bangladesh: A Case Study. Academy of Taiwan Business

Management Review, 8(3), 10-18.

Minbaeva, D.B.(2005) 'HRM practices and MNC knowledge transfer', Personal Review, Vol 34, No 1, PP 125-44.

Martin, G. \& Beaumont, P. (1999). Co-ordination and control of human resource management in

multinational firms: the case of CASHCO, International Journal of Human Resource

Management, 10(1) $101-121$.

Ngo, H., Tschudi, C., Gull, K., and Ullu, E. (1998). Double-stranded RNA induces MRNA degradation in Trypanosoma brucei. Proc. Natl. Acad. Sci. USA 95, 14687-14692.

Nyambegera, S. M., Sparrow, P. R., \& Daniels, K. (2000). The impact of cultural value Organizational

Dynamics, Winter: 35-46.

Paauwe, J., Boselie, J.P. \& Richardson, R. (2002). Human Resource Management, Institutionalization and Organizational Performance: a comparison of hospitals, hotels and local governments. Rotterdam School of Economics. Erasmus University Rotterdam.

Panayotopoulou, L., D. Bourantas, et al. (2003). "Strategic human resource management and its effects on firm performance: an implementation of the competing values framework." International Journal of Human Resource Management 14(4): 680-699.

Paul, A. K. and R. N. Anantharaman (2003). "Impact of people management practices on organizational performance: analysis of a causal model " International Journal of Human Resource Management 14(7): 1246-1266.

Pfeffer, J. (1994). Competitive Advantage Through People. Boston, MA, Harvard Business School Press.

Pfeffer, J. (1998). Seven practices of successful organizations. California Management Review, Vol. 40, No. 2, pp.96-124. 
Pratt, M. G., \& Rafaeli, A. 1997. Organizational dress as a symbol of multilayered social identities. Academy of Management Journal, 40 (4): 862-898.predictions'. Academy of Management Journal. 39(4): 802-35.Resource Management, 12, 1107-1125.

Sackmann, Sonja A. \& Phillips, Margaret E. (2004). Contextual Influences on Culture Research: Shifting Assumptions for New Workplace Realities, in IJCCM International Journal for Cross-Cultural Research, 4(3), S. 371-392.

Schuler, R.S. and Jackson S.E. (2007) (eds.) Strategic Human Resource Management: A Reader. London: Blackwell Publishers.

Schuler, R.S. (1992). Strategic human resource management: Linking the people with the strategic needs of the business. Organizational Dynamics, 21(3), 18-32.

Schuler, R.S., Dowling, P.J., \& De Cieri, H. (1993). An integrative framework of strategic international human resource management. Journal of Management, 19, 419-459.

Shah, R. \& Ward, P. T., 2003. Lean manufacturing: context, practice bundles, and performance. Journal of Operations Management, 21 (2), 129-149.

Siengthai, S. \& Bechter, C. (2001). Strategic Human Resource Management and Firm Innovation,OP.CIT.,p 38.

Søndergaard, M. (1994). "Hofstede's consequences: A study of reviews, citations and replications." Organization Studies 15(3): 447.

Stavrou-Costea, E. (2002). The role of human resource management in today's organizations: The case of Cypus in comparison with the European Union. Journal of European Industrial Training, 26(6), 261-268.

Sundaram, A. K. und Black, S. J. (1992): The Environment and internal organization of multinational Enterprises, Academy of Management Review, 17, 4, S. 729-757.

Teagarden, M., Butler, M., \& Glinow, Von M. (1992). “ Mexico’s Maquiladoras.”

Triandis, H. C. (1994). Culture and social behavior. New York: McGraw-Hill, Inc.

Tzafrir, S. S. (2005). "The relationship between trust, HRM practices and firm performance." International Journal of Human Resource Management 16(9): 1600-1622.

Thang, L.C. (2004). 'Managing Human Resources In Vietnam: An Empirical Stuidy Of An Economy In Transition'. Dissertation, No. SM-04-07, School of Management, Asian Institute of Technology, Thailand.

Tung, R. L. (1988). The new expatriates: Managing human resources abroad. Cambridge, Mass.: Ballinger.

Wright, P. M., T. M. Gardner, et al. (2001). "Measurement error in research on human resources and firm performance: additional data and suggestions for future research " Personnel Psychology 54(4): 875-901.

Wright, P.M., Snell, S.A., and Dyer, L. (2005). New models of strategic HRM in a global context. International Journal of Human Resource Management, 16, 875-881.

Youndt, M.A. Snell, S.A., Dean, J.W. \& Lepak, D.P. (1996). Human resource management, manufacturing strategy and firm performance. Academy of Management Journal, 39(4), 836866. 